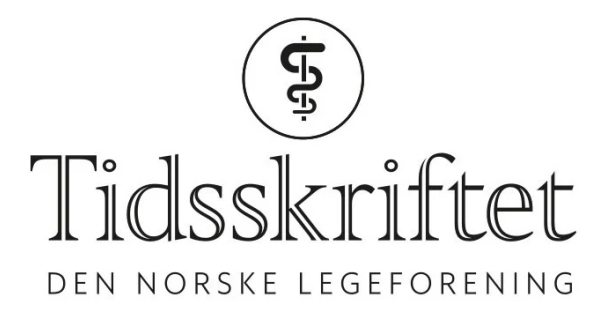

\title{
Svelgevansker etter strålebehandling
}

KRONIKK

ARNE MOSBERG

Sunnaas sykehus

*Nåværende adresse:

Skogveien 21

1430 Ås

\section{MARIBETH CAYA RIVELSRUD}

Email: maribeth.rivelsrud@sunnaas.no

Sunnaas spesialpedagogiske kompetansesenter

Sunnaas sykehus

1450 Nesoddtangen

Svelgevansker kan oppstå, vedvare eller forverres lang tid etter strålebehandling av kreft i hode-hals-området. Det kan synes som om helsepersonell som møter pasientene, har varierende grad av kjennskap til mulige tiltak, og oppfølgingen bør i større grad sentraliseres. 
Noen av pasientene som har gjennomgått strålebehandling ved kreft i hode-hals-området henvises til Sunnaas sykehus til vurdering og behandling av senfølger i form av svelgevansker. I denne kronikken ønsker vi å sette søkelys på problemstillingen og diskutere aktuelle tiltak.

\section{Forekomst}

Med kreft i hode-hals-regionen mener vi her kreft lokalisert til nese/bihuler, munnhule, spyttkjertler, svelg og strupehode. I 2008 ble det oppdaget 622 nye tilfeller. Det tilsvarte 2,4 $\%$ av totalt antall nyoppdagede krefttilfeller i Norge (1). I litteraturen angis en forekomst av svelgefunksjonsvansker etter postoperativ strålebehandling eller strålebehandling kombinert med kjemoterapi av kreft i dette området på 22-48\% (2) $)$. Etter vår erfaring kan disse plagene forverres flere år etter avsluttet primærbehandling og avsluttet rutinekontrollopplegg. Dette bekreftes også i litteraturen hvor det angis at svelgevansker kan oppstå så sent som 20 år etter primærbehandlingen (3).

Pasientene er ofte svært plaget i forbindelse med næringsinntak, men også mer generelt pga. smerter, dårlig tannstatus, munntørrhet, sikling, vekttap, og usikkerhet angående egen situasjon og videre forløp. Tilstanden er ofte sosialt hemmende og psykisk krevende, og kan føre til at pasientene unngår sosiale sammenhenger hvor næringsinntak inngår. I tillegg har de ofte talevansker som hemmer kommunikasjon, bidrar til uønsket oppmerksomhet og ytterligere legger hindringer i veien for en normal sosial fungering, både yrkesmessig og i fritiden.

\section{Endringer i vev og funksjon}


Skade av spyttkjertler (glandula parotis, submandibularis, sublingualis) gir endring i mengde og sammensetning av produsert spytt. Reduksjon av mengden av enzymer kan indirekte gi redusert tyggeevne og svelgefunksjon, og gi munntørrhet som medfører $\emptyset \mathrm{kt}$ risiko for karies. Osteoradionekrose kan også oppstå og øke pasientens plager i form av henfall av beinsubstans, tannløsning og sår i slimhinner over kjevebeinet som ikke vil gro. Stråleterapi gir fibrose og arrdanning. Dette leder til økt rigiditet i vevet og fører til nedsatt evne til å gape. Ved uttalt fibrose kan det oppstå strikturer i svelg og spiserør. I tillegg kan dette føre til redusert styrke i tungemuskulatur og nedsatt koordinasjon av tungebevegelser, redusert evne til å presse tungeroten mot bakre svelgvegg og nedsatt heving av strupehodet i forbindelse med svelging. Konstriktormuskulaturen i pharynx kan påvirkes, med redusert evne til videretransport av bolus som følge. Strupelokkets bevegelighet svekkes. Det medfører redusert evne til å stenge for luftveiene under svelgeprosessen. Tilstanden ledsages også ofte av nedsatt sensibilitet. Dette kan vanskeliggjøre utløsing av svelgerefleks og evne til rensing av pharynx. Pasientene kan derved aspirere uten at de merker det (fig 1, video). Strålebehandling kan gi lymfødem som skyldes opphoping av lymfe interstitielt som følge av destruksjon av lymfekar. Mukositt, inflammasjon i de mukøse membranene, oppstår oftest i den første fasen etter stråleterapi. Tilstanden kan være svært smertefull, og reduserer pasientens mulighet til å innta fast næring og væske $(4,5)$.
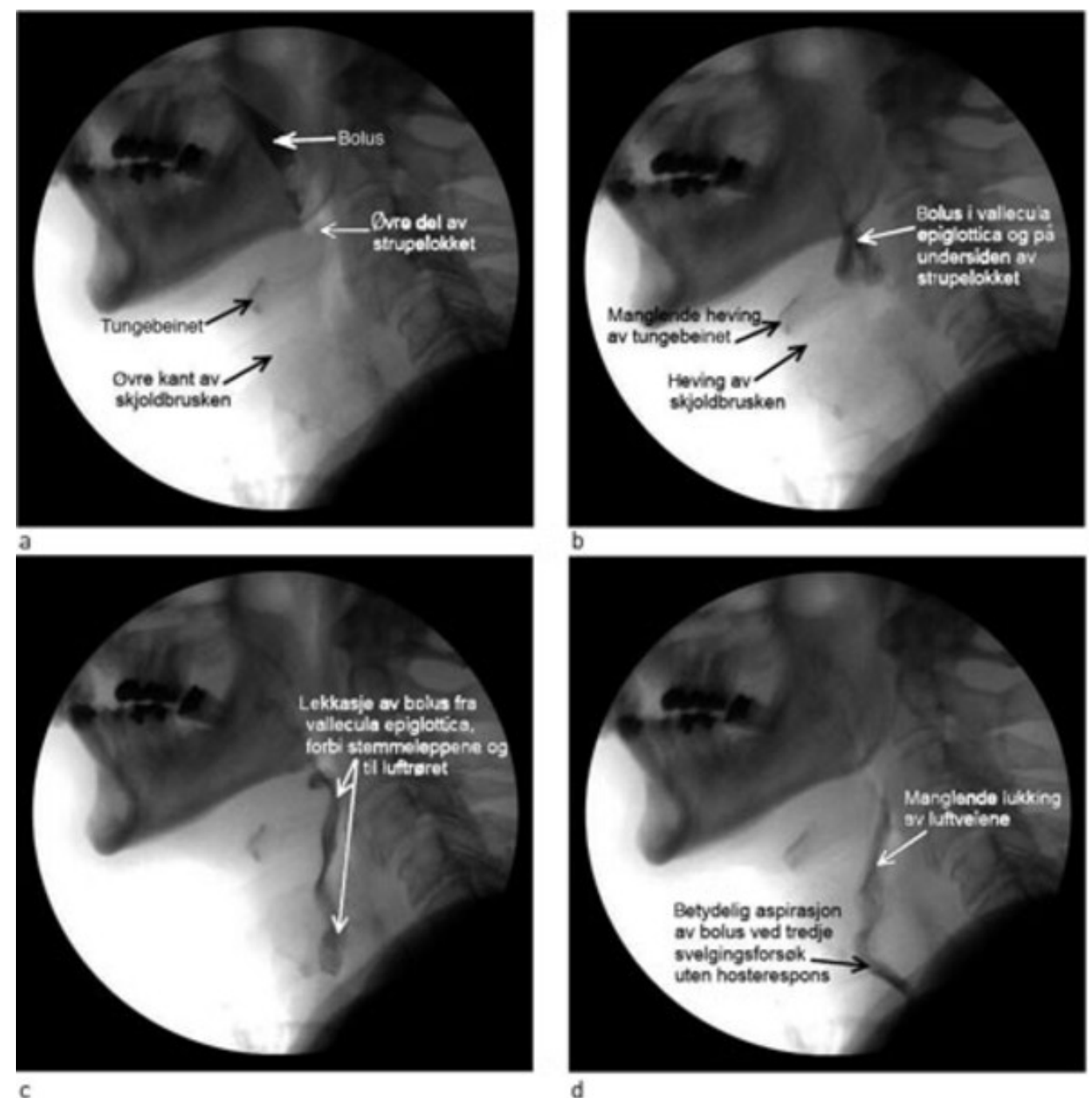

Figur 1 Bilder fra videofluoroskopiopptak av kreftpasient etter strålebehandling. Bildene (a-d) viser orofaryngeale svelgevansker som fører til aspirasjon

\section{Hva kan gjøres?}


$85 \%$ av alle kreftpasienter opplever feil- eller undernæring pga. smerter ved næringsinntak, svelgevansker, slapphet, kvalme, endret smakssans og nedsatt appetitt (4). Det er derfor viktig med kartlegging og monitorering av ernæringen og eventuelt. supplering av inntaket for å forhindre utvikling av mangeltilstander som igjen kan medføre nedsatt sårtilheling, og nedsatt beskyttelse mot infeksjoner. Oppfølging av pasienter som er aktuelle for behandling for kreft i hode-hals-området bør være tverrfaglig og teambasert (4, 6). Etter vårt syn gjelder dette generelt for pasienter med svelgevansker, og man bør være særlig aktpågivende overfor senvirkninger hos dem som har gjennomgått strålebehandling. Det foreligger ikke internasjonale anbefalinger for dette. Men vi mener at pasientene, før terapeutiske tiltak settes inn mot kreftsykdommen, og basert på individuell kartlegging, bør få opplæring i øvelser med sikte på å opprettholde og eventuelt $\varnothing$ ke munnmotiliteten. Ved svelgevansker skal disse kartlegges.

Etter primærbehandlingen av kreftsykdommen må de pasientene som har svelgevansker, gjennomgå en ny vurdering av svelgefunksjonen, og eventuelt få råd med hensyn til tilpasset ernæring og vurdering av indikasjon for opplæring i spesifikke kompensatoriske svelgestrategier/øvelser. En del vil også ha behov for regelmessig oppfølging med kontroll og eventuelt justering av igangsatte tiltak. Carroll og medarbeidere har vist at svelgetrening før primærbehandling av denne typen kreft gir bedre svelgefunksjon etter intervensjon enn ingen trening før kreftbehandlingen (7.). I tillegg er det vist at postintervensjonell livskvalitet knyttet til svelging bedres ved denne typen intervensjon (多).

Mye av utviklingsarbeidet for denne typen pasientoppfølging har foregått i USA, i et samarbeid mellom øre-nese-hals-spesialister og "speech and language pathologists» (tilsvarende våre logopeder). Utdanningen til slike logopeder inkluderer undervisning i utredning og behandling av svelgevansker. Slik undervisning er nå også en del av utdanningen til logopeder her i Norge.

I utredningen av pasienter med svelgevansker benyttes videofluoroskopi (røntgenfilming med digitalt videoopptak av svelgeprosessen med kontrast). Metoden er utviklet av Logemann (9.). Dette suppleres eventuelt med en fiberoptisk endoskopisk undersøkelse av svelging (FEES) - først beskrevet av Langmore og medarbeidere (므). Ved hjelp av disse teknikkene kan man også danne seg et inntrykk av hvilken effekt forskjellige kompensatoriske tiltak, som for eksempel justering av hode-/sittestilling, spesielle svelgeteknikker, ernæringskonsistenser og mengde per svelging har på svelgingen. Dette gir et godt grunnlag for å gi pasienten råd om hvilke ernæringskonsistenser og -mengder som er trygge for ham eller henne til enhver tid. Grundig anamneseopptak, observasjon og undersøkelse av motilitet og kraft i aktuelle strukturer, samt prøvesvelging uten kontrast, skal alltid fortas forut for videofluoroskopi og endoskopi. Tiltakene må ses i sammenheng med pasientens generelle helsetilstand og prognose, og det er derfor viktig at legen er medlem av behandlingsteamet.

\section{Hvor bør ansvaret ligge?}

I regi av Oslo universitetssykehus, Rikshospitalet og Helse $§ ø r-\emptyset$ st er det utarbeidet et gratis, nettbasert oppslagsverk for utredning og behandling av kreft, deriblant kreft i hodehals-området (1ㅡ). Her fremgår det at kontroll det første året etter primærbehandling bør foregå i regi av behandlende avdeling, siden hos henvisende lege/avdeling. Vår kliniske erfaring tilsier at en del av pasientene får $\emptyset$ kende svelgevansker langt ute i sykdomsforløpet, og at det da i praksis kan foreligge uklarhet om hvordan disse skal ivaretas og hvor pasientene kan henvises. Kartlegging og opptrening av pasienter med svelgevansker er høyt spesialisert arbeid, og må nok til en viss grad sentraliseres. Behandlingsteamet bør etter vårt syn ideelt sett bestå av logoped, sykepleier/ernæringsfysiolog og lege med interesse for feltet. Pasientene utvikler ikke 
sjelden muskulære spenningstilstander og/eller psykiske følgevirkninger som påvirker evnen til å drive svelgetrening. Teamet bør derfor ha kontakt med fysioterapeut og psykolog som kan stille opp ved behov.

Et nasjonalt nettverk for fagutvikling og erfaringsutveksling innenfor dysfagifeltet er nå etablert. Nettverket domineres av logopeder, med sporadisk oppmøte av lege (radiologi/fysikalsk medisin og rehablitering). Gruppen på 10-15 personer møtes 3-4 ganger per år. Erfaringene er at de utstyrsmessige og personalmessige ressursene til oppfølging av pasienter med dette problemet varierer betydelig i de forskjellige helseregionene. Det virker som om tilbudet lokalt avhenger mye av om det finnes enkeltpersoner som har tilstrekkelig kunnskap og oppmerksomhet rettet mot problemstillingen. Legenes grad av involvering varierer også betydelig. Etter vår mening $b ø r$ hver helseregion ha et team for oppfølging av denne pasientkategorien. Teamene bør i tillegg kunne ta imot henvisninger for utredning og opptrening av uttalte svelgefunksjonsvansker hos andre pasientkategorier, som pasienter med cerebrovaskulære eller traumatiske hjerneskader, andre nevrologiske lidelser (cerebral parese, multippel sklerose, Parkinsons sykdom, amyotrofisk lateral sklerose) samt multifunksjonshemmede i sin region.

Vi håper med dette å bidra til å sette sterkere søkelys på aktuelle pasientgruppe som bør få et mer ensartet og strukturert tilbud.

\section{Oppgitte interessekonflikter:}

Ingen

\section{LITTERATUR}

1. Kreftregisteret. Cancer in Norway 2008. www.kreftregisteret.no/no/Generelt/Nyheter/Kreftstatistikken-publiseres-i-dag/ (23.8.2010).

2. Nguyen NP, Moltz CC, Frank C et al. Dysphagia severity following chemoradiation and postoperative radiation for head and neck cancer. Eur J Radiol 2006; 59:453-9.

3. Oppenheimer R, Finkel R, Brennan A. Treatment of radiationinduced fibrosis of the face with manual compression therapy. Ear Nose Throat, 2004; 83, 478-80.

4. Dietrich-Burns K, Messing B, Farrell S et al. Fundamentals for the speech-language pathologist working with head and neck cancer. Perspectives on Swallowing and Swallowing Disorders 2006; 15: 3-9.

5. Lazarus CL. Swallowing disorders after organ preservation treatment for head and neck cancer. Perspectives on Swallowing and Swallowing Disorders 2001; 10:11-4.

6. Michell AO, Karahatay S. Head and neck cancer surgery and the speech-language pathologist. Perspectives on Swallowing and Swallowing Disorders 2006; 15: 9-14.

7. Carroll WR, Locher JL, Canon CL et al. Pretreatment swallowing exercices improve swallow function after chemoradiation. Laryngoscope 2008; 118:39-43.

8. Kulbersch BD, Rosenthal EL, McGrew BM et al. Pretreatment, preoperative swallowing exercices may improve dysphagia quality of life. Laryngoscope 2006; 116; 883-6.

9. Logemann JA. Manual for the videofluorographic study of swallowning. San Diego, CA: College Hill, 1986.

10. Langmore SE, Schatz K, Olsen N. Fiberoptic endoscopic examination of swallowing safety, a new procedure. Dysphagia 1988; 2: 216-9.

11. Onkologisk nettverk. www.oncolex.no (23.8.2010).

Publisert: 4. november 2010. Tidsskr Nor Legeforen. DOI: 10.4045/tidsskr.10.0474

Manuskriptet ble mottatt 23.4. 2010 og godkjent 2.9. 2010. Medisinsk redaktør Siri Lunde.

(c) Tidsskrift for Den norske legeforening 2023. Lastet ned fra tidsskriftet.no 26. april 2023. 
